\title{
Só me interessa o que não é meu
}

Frederico Coelho ${ }^{1}$

\section{RESUMO:}

A máxima "Só me interessa o que não é meu", presente no Manifesto Antropofágico de Oswald de Andrade, funciona cada vez mais como perspectiva para analisarmos algumas dinâmicas do mundo contemporâneo, não apenas no âmbito da cultura, mas também em outras áreas como a política e a economia. Fazendo um breve balanço da questão da alteridade e de seus desdobramentos como motor desse impulso antropofágico contemporâneo, o artigo visa provocar alguns consensos e atualizar de forma critica a famosa máxima de Oswald sobre o interesse em relação ao outro.

Palavras Chave: Manifesto Antropófago; alteridade; contemporaneidade

\section{ABSTRACT:}

The statement "I am only interested in what's not mine", in Oswald de Andrade's Cannibal Manifesto, is taken here as a starting point to analyze alterity and some dynamics of contemporary world.

Key-words: Cannibal Manifesto; alterity; contemporaneity

\footnotetext{
1 Professor de Literatura e Artes Cênicas da PUC-Rio e autor dos livros Eu, brasileiro, confesso minha culpa e meu pecado - cultura marginal no Brasil dos anos 1960/1970 (Civilização Brasileira, 2010) e Livro ou Livro-me: os escritos babilônicos de Hélio Oiticica (EdUERJ, 2010).
} 
Só me interessa o que não é meu. Essa frase é uma das primeiras do Manifesto Antropofágico, maio de 1928, publicado na Revista de Antropofagia $\mathrm{n}^{\circ} 1.81$ anos atrás.

O manifesto, talvez o mais relido, retomado, repisado, rebolado da nossa história cultural, enumera sentenças proféticas como "O que atropelava a verdade era a roupa, o impermeável entre o mundo interior e o mundo exterior. A reação contra o homem vestido. O cinema americano informará" ou "A fixação do progresso por meio de catálogos e aparelhos de televisão. Só a maquinaria. E os transfusores de sangue”.

Mas voltemos ao interesse pelo o que é do outro. Hoje, a alteridade é valor de mercado. Se interessar pelo que é do outro é praxe na dinâmica capitalista, no mercado de bens culturais, na indústria da moda e do design, nas altas culinárias e, principalmente, no mercado fonográfico. Esse "outro" que faço referência não compete com "as coisas nossas" do samba de Noel Rosa. Ao contrário. É na junção do orgulho local com o temor/amor pelo "outro" que encontramos a antropofagia enquanto engrenagem do mercado.

Não tenho intenção de dar conta da vasta literatura existente sobre as relações históricas entre países centrais e periféricos ("eles" x "os outros"). Este debate sobre cultura, mercado e alteridade, porém, traz à tona necessariamente o tema incontornável dos consumos e da circulação de objetos culturais através de espaços teoricamente demarcados como "centro" e "periferia" ou "local" e "global".

A partir de nossa condição histórica de colônia e - já nos tempos do capitalismo industrial mundializado - periferia, diversos trabalhos no campo da sociologia, da ciência política, da filosofia, da crítica literária, da teoria da arte e áreas afins das ciências humanas tentaram, de alguma forma, definir nossa "identidade nacional" e, por consequiência, nossas especificidades culturais. Isto é, definir como ser "o outro" em um mundo dividido por geopolíticas e mercados consumidores.

Sem entrarmos aqui em citações de tantos textos clássicos - cuja trajetória esquemática vai desde os marcos fundadores do pensamento nacional no século XX como os livros de Gilberto Freyre, Sérgio Buarque de Holanda, Caio Prado Junior, Oliveira Vianna ou Paulo Prado até os textos modernistas de Mário e do próprio Oswald de Andrade, passando pelo período desenvolvimentista dos anos 1950 com toda a produção do ISEB 
e da escola de sociologia da USP e chegando aos novos caminhos da crítica contracultural formulada no bojo da crise do pensamento de esquerda do fim dos anos 1960 -, a idéia de que éramos um país cuja "cultura popular" se encontrava em conflito claro com uma cultura capitalista industrial e internacional que invadia nosso espaço criativo e intelectual foi uma constante.

Para alguns, esse processo de afluência do centro sobre nós, a periferia, era inevitável e deveria ser o ponto de partida para atualizarmos nossa história e criarmos nossa própria face da modernidade - o processo sintetizado por Oswald no conceito de Antropofagia. Para outros, tal processo deveria ser combatido com veemência, com o intuito de preservar nossos "valores" e especificidades locais, ancorados em idéias como a tradição e a sabedoria popular.

De um lado, a expansão da ideia de nação em direção ao novo e ao resto do mundo. De outro, o fechamento estratégico em torno do "caráter nacional" e de suas especificidades. Basta lembrar aqui, para ilustrar esse processo, expressões presentes até hoje em algumas áreas como "invasão cultural", "ideias fora do lugar" e "alienação" ou os debates ocorridos em momentos marcantes da história cultural do país como o Modernismo de 1922 (mesmo com suas diferenças e contradições dentre as perspectivas de seus principais participantes), o CPC da UNE entre 1961 e 1964 e o surgimento do Tropicalismo em 1967. Debates que, até hoje, ecoam nas políticas públicas e nos financiamentos em áreas como cinema, teatro e artes plásticas: internacionalizar ou nacionalizar? Tate Modern ou Aleijadinho? Nação Zumbi ou Nei Lopes?

Com a modernização forçada, feita de cima para baixo e de forma autoritária pelo governo militar brasileiro durante o final dos anos 1960 e durante os anos 1970, novos elementos passaram a compor esse debate. Uma maior circulação de bens de consumo e informação fez com que novos atores sociais e demandas criassem clivagens nos parâmetros definidores de conceitos como "popular" ou "nacional". Novelas exibidas em todo o país, revistas internacionais, uma avançada indústria fonográfica multinacional e um mercado publicitário em expansão eram alguns dos novos elementos que relativizaram universos claramente demarcados no passado recente entre campo e cidade, alta e baixa cultura e, por fim, centro e peri iferia. 
Pensando esse quadro a partir de uma expressão presente em alguns textos do sociólogo Renato Ortiz, a internacionalização da cultura brasileira nesse momento passou por um período agudo de transformação e se aprofundou nos anos 1980, quando as bases do que convencionalmente chamamos de globalização foram estabelecidas no país. A expansão desse processo permanece até hoje em ritmo acelerado. Com o advento das antenas parabólicas, da internet e de todas as suas consequiências vinculadas à era digital, vivemos num momento de revisão e crítica das ideias fundadoras do pensamento social brasileiro em particular, e periférico em geral.

Tal internacionalização da nossa cultura pode ser explicitada a partir de uma série de eventos e estudos feitos ao longo das últimas décadas. Hoje em dia, principalmente no campo da cultura, é ponto pacífico pensar que em muitos segmentos não somos apenas locais ou nacionais, mas sim universais. Artes, moda, mídia, mercado ou comportamento, são instâncias situadas em um novo espaço analítico. Dentre as novas teorias para se pensar esse espaço, muitas apostam justamente na sobreposição ou na convivência - ora pacífica, ora conflituosa - dos diferentes aspectos culturais que sempre basearam os aspectos do local, do regional, do nacional e do global. Alguns autores latino-americanos já sugeriram ao longo das últimas décadas conceitos-chave para pensarmos esse tema como o "entre-lugar" de Silviano Santiago, a "hibridação" de Nestor García Canclini ou, indo mais atrás no tempo, a "transculturação", apresentada na obra do antropólogo cubano Fernando Ortiz.

Se no passado a cultura foi o cerne das invenções de nacionalidade, arma de doutrinação de ideários políticos e porto seguro para se pensar a autenticidade de um povo ou país, hoje em dia ela se encontra em situação oposta. É justamente nesse espaço indefinido do entre, do inter e do trans que passado e futuro, localidade e circularidade, dentro e fora, alto e baixo, puro e impuro e tantos outros pares excludentes passam a não só conviver, como a se alimentar, formando novas possibilidades estratégicas na hora de produzir - e vender - cultura no Brasil em particular e em países periféricos em geral.

Comer o outro, como Oswald proclama, é apropriar-se da vitalidade criativa alheia. O sucesso da arte chinesa nos grandes mercados mundiais, o Oscar de um filme indiano filmado por um inglês (ex-colonizador do país), Curumin lançando Japan pop show por um selo californiano de Rap, o trânsito frenético de ritmos musicais eletrônicosperiféricos dentre os diversos países, são brevíssimos sintomas culturais. No âmbito 
político-econômico, para nos atermos ao jornal, o mundo nunca foi tão dependente da questão do outro e da alteridade - e nunca tão temeroso de sua livre circulação entre centros e periferias. Conflitos étnicos balizando comunidades econômicas internacionais, jogos de xadrez na Unesco e no G-20, espanhóis ofendidos pelo nosso ministro da econômica comprando gordas fatias de nosso mercado editorial, os EUA precisando do Paquistão e do Afeganistão para vencer terroristas, os times ingleses, italianos, espanhóis, franceses de futebol lotados de jogadores estrangeiros que, se estivessem nas ruas, seriam vistos como invasores. O OUTRO é o espectro que ronda o capitalismo, e não o proletariado como outro Manifesto - o comunista - previa.

Oswald mais uma vez: "O amor cotidiano e o modus vivendi capitalista. Antropofagia. Absorção do inimigo sacro. Para transformá-lo em totem. A humana aventura. A terrena finalidade". A absorção do inimigo sacro talvez seja o limite da vitória da Antropofagia. O ódio religioso grassa na Terra, a busca de refúgio espiritual é o caminho do beco sem saída e da redenção de muitos, fartos com a dinâmica de comer o outro, dinâmica que Oswald vislumbrou como solução e miséria, como salvação e condenação em uma civilização materialista. No fim, tudo vira filme, youtube e novela. A índia e a Lapa, Madonna e o Papa.

Só me interessa o que não é meu. 